\title{
The emerging role of heterodimerisation and interacting proteins in ghrelin receptor function
}

\author{
Maria L Price ${ }^{1,2}$, Cameron D Ley ${ }^{1,2}$ and Caroline M Gorvin 101,2 \\ 1Institute of Metabolism and Systems Research and Centre for Endocrinology, Diabetes and Metabolism, University of Birmingham, Birmingham, UK \\ ${ }^{2}$ Centre of Membrane Proteins and Receptors (COMPARE), Universities of Birmingham and Nottingham, Birmingham, UK
}

Correspondence should be addressed to C M Gorvin: C.Gorvin@bham.ac.uk

\begin{abstract}
Ghrelin is a peptide hormone secreted primarily by the stomach that acts upon the growth hormone secretagogue receptor (GHSR1), a G protein-coupled receptor whose functions include growth hormone secretion, appetite regulation, energy expenditure, regulation of adiposity, and insulin release. Following the discovery that GHSR1a stimulates food intake, receptor antagonists were developed as potential therapies to regulate appetite. However, despite reductions in signalling, the desired effects on appetite were absent. Studies in the past 15 years have demonstrated GHSR1 a can interact with other transmembrane proteins, either by direct binding (i.e. heteromerisation) or via signalling cross-talk. These interactions have various effects on GHSR1a signalling including preferential coupling to one pathway (i.e. biased signalling), coupling to a unique $\mathrm{G}$ protein ( $\mathrm{G}$ protein switching), suppression of GHSR1a signalling, and enhancement of signalling by both receptors. While many of these interactions have been shown in cells overexpressing the proteins of interest and remain to be verified in tissues, substantial evidence exists showing that GHSR1a and the dopamine receptor D1 (DRD1) form heteromers, which promote synaptic plasticity and formation of hippocampal memory. Additionally, a reduction in GHSR1a-DRD1 complexes in favour of establishment of GHSR1a-A $\beta$ complexes correlates with Alzheimer's disease, indicating that GHSR1a heteromers may have pathological functions. Herein, we summarise the evidence published to date describing interactions between GHSR1a and transmembrane proteins, discuss the experimental strengths and limitations of these studies, describe the physiological evidence for each interaction, and address their potential as novel drug targets for appetite regulation, Alzheimer's disease, insulin secretion, and inflammation.
\end{abstract}

\section{Introduction}

Ghrelin is a 28-amino acid gut-derived hormone, referred to as the 'hunger hormone', due to its role in stimulating appetite and initiating food intake (Kojima et al. 1999). Ghrelin is secreted in an inactive form primarily by the stomach. Activation requires acylation by the ghrelin-O- acyltransferase (GOAT) enzyme, which is itself released under fasted conditions (Gutierrez et al. 2008). Ghrelin acts by binding to the growth hormone secretagogue receptor-1 (GHSR1), a G protein-coupled receptor (GPCR) expressed in the brain (primarily on hypothalamic and (c) 2021 The authors Published by Bioscientifica Ltd. Printed in Great Britain

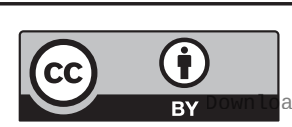

This work is licensed under a Creative Commons Attribution 4.0 International License. 
hippocampal neurons) and endocrine tissues (including the pituitary and pancreas) (Howard et al. 1996, Kojima et al. 1999). Ghrelin receptor functions include effects on growth hormone (GH) secretion, appetite regulation, energy expenditure, adiposity, insulin release, and gastric emptying. GHSR1 exists in two forms; the active, signalling form, GHSR1a, and an inactive form, GHSR1b, a splice variant with transmembrane (TM) helices 6 and 7 deleted (Howard et al. 1996). GHSR1 primarily signals via $\mathrm{G} \alpha_{\mathrm{q} / 11}$-phospholipase $\mathrm{C}$ (PLC), to activate intracellular $\mathrm{Ca}^{2+}\left(\mathrm{Ca}^{2+}{ }_{\mathrm{i}}\right)$ mobilisation, and the receptor exhibits considerable constitutive activity. In 2018, an endogenous antagonist and inverse agonist of GHSR1a, liver-expressed antimicrobial peptide 2 (LEAP2), with similar potency to ghrelin, was discovered. LEAP2 prevents ghrelin-mediated effects on food intake, GH release, and maintenance of glucose levels during chronic caloric restriction (Ge et al. 2018).

Following the discovery that GHSR1a stimulates food intake, research focused on developing antagonists to the receptor as therapies to regulate appetite. However, despite reductions in signalling when used in cell-based assays, these GHSR1a antagonists reduced GH secretion, but stimulated appetite in rats and dogs (Costantini et al. 2011, Hassouna et al. 2013). This is perhaps not unexpected given the complex role of GHSR1a in adiposity and energy expenditure that is now understood (Muller et al. 2015), and it is likely that different strategies will be required to target GHSR1a. In the past 15 years, new insights into the complexity of GHSR1a signalling have emerged that could yield novel therapeutic targets. These include the identification of interacting proteins, such as the melanocortin receptor accessory protein-2 (MRAP2), and increasing evidence that GHSR1a can form heteromers with several GPCRs, resulting in modification of GHSR1a signalling (Fig. 1 and Tables 1, 2). The ability of GHSR1a to modify signalling when dimerised with other receptors, even in the absence of ligand, could help explain why GHSR1a is widely expressed, including in some brain regions that are inaccessible to circulating ghrelin (Perello et al. 2019). In such cells, GHSR1a may act to regulate the functioning of other GPCRs, rather than to mediate ghrelin-specific actions. The potential to target GHSR1a heteromeric complexes could provide new avenues to reduce GHSR1a signalling in specific target tissues to modify ghrelin-dependent and -independent functions. This review will describe the GHSR1a interactions identified to date, and explore their feasibility as therapeutic targets.

\section{GHSR1a interactions with the melanocortin receptor accessory protein-2 (MRAP2)}

MRAP2 is a single transmembrane protein that is highly expressed in the hypothalamus and adrenal gland (Chan et al. 2009). It was identified as a regulator of the melanocortin family of GPCRs but has since been shown to interact with other GPCRs involved in energy homeostasis, including the prokineticin receptor-1 and orexin-1 receptor (Chan et al. 2009, Sebag et al. 2013, Rouault et al. 2017). MRAP2 stimulates growth in zebrafish; while deletion of the protein causes severe obesity in mice, and genetic variants are associated with obesity in humans (Asai et al. 2013, Sebag et al. 2013). Observations that MRAP2-deficient mice ate $30 \%$ less food compared to their WT littermates following a 24-h fast, indicated that MRAP2 may also have an important role in hunger sensing and in the starvation-mediated activation of orexigenic agouti-related peptide (AGRP) neurons, similar to GHSR1a (Srisai et al. 2017). Indeed, MRAP2-knockout mice had reduced fasting-induced activation of AGRP neurons (decreased cFos activity and failure to induce Agrp and neuropeptide Y (Npy) gene expression); while mice with specific deletion of MRAP2 from AGRP neurons failed to develop obesity and ate significantly less after a 24-h fast (Srisai et al. 2017). This led to the hypothesis that MRAP2 may also interact with GHSR1a, which was confirmed by co-immunoprecipitation and NanoBiT experiments in Chinese Hamster Ovary (CHO) cells (Srisai et al. 2017). Furthermore, when MRAP2 is deleted from mice, ghrelinmediated functions are impaired. Thus, in global knockout mice, ghrelin-induced AMPK phosphorylation and cFos activity were reduced, while ghrelin-mediated increases in food intake were absent. In mice with MRAP2 deleted from AGRP neurons, GCamp6 calcium oscillations were impaired, indicating that MRAP2 potentiates GHSR1a signalling in these neurons.

A subsequent study investigated the mechanism by which MRAP2 enhances GHSR1a signalling in transfected CHO cells. MRAP2 had no effect on GHSR1a surface expression, ghrelin affinity, or guanine nucleotide exchange factor activity (i.e. the ability of the $\mathrm{G} \alpha_{\mathrm{q}}$ protein to exchange GDP for GTP) (Srisai et al. 2017, Rouault et al. 2020). MRAP2 was shown to increase GHSR1a activity by inhibiting the receptor's constitutive activity, using inositol monophosphate $\left(\mathrm{IP}_{1}\right)$ assays. In cells transfected with increasing concentrations of GHSR1a, IP ${ }_{1}$ responses increased in the absence of ligand, but when MRAP2 was co-expressed, this constitutive activity was lost

This work is licensed under a Creative Commons Attribution 4.0 International License.

ded from Bioscientifica.com at 04/26/2023 09:31:29AM 

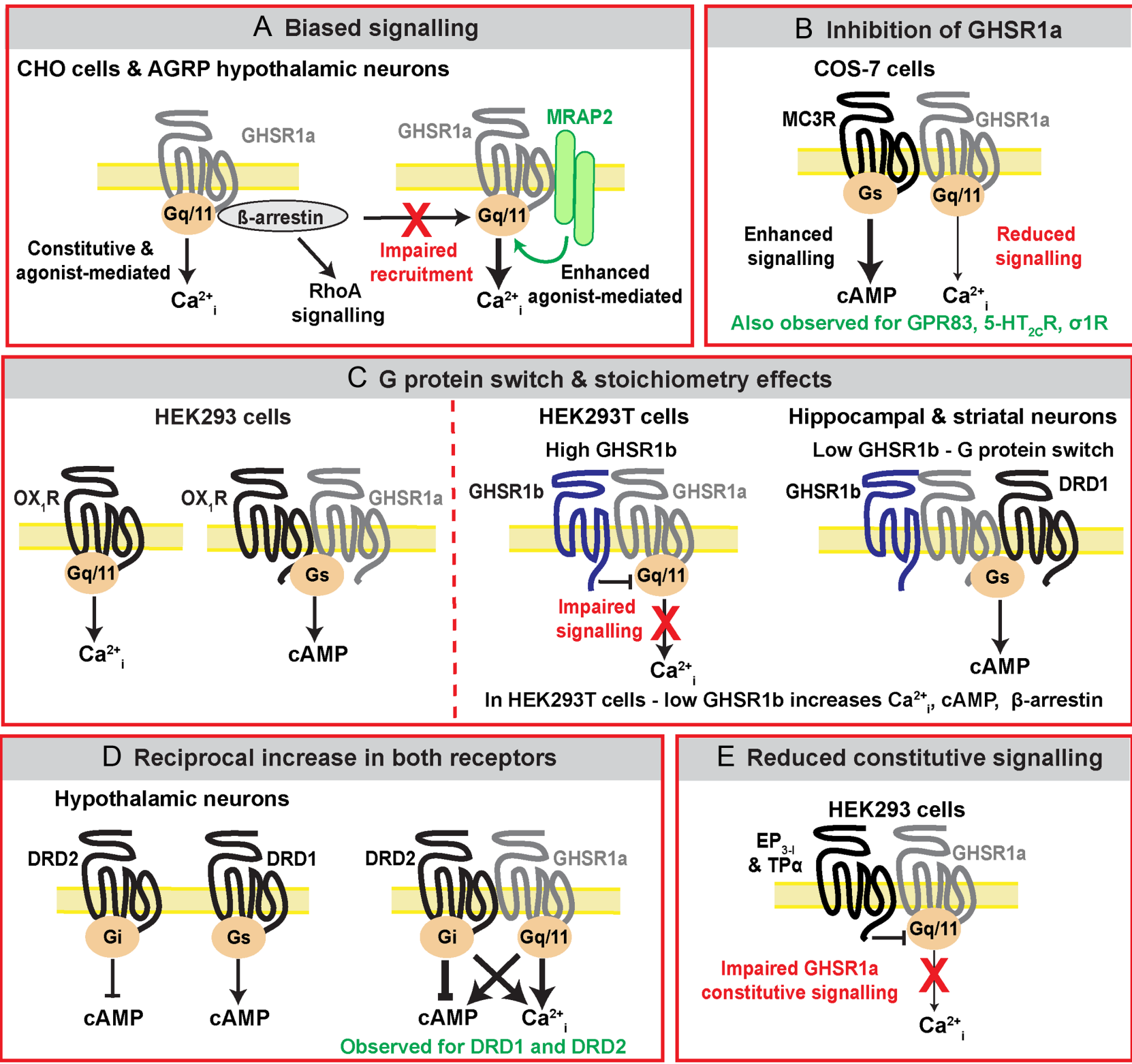

E Reduced constitutive signalling

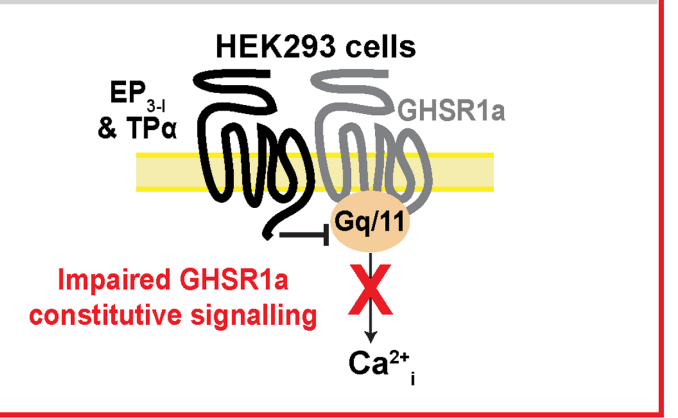

Figure 1

Mechanisms by which GHSR1a signalling is modified by interacting proteins. Schematic showing the different mechanisms by which GHSR1a signalling is modified by interactions with transmembrane proteins. All diagrams depict monomeric receptors, although there is evidence that heterotetramers may occur. GHSR1a is understood to primarily signal via $\mathrm{G}_{\mathrm{q} / 11}$ pathways to activate $\mathrm{Ca}^{2+}{ }_{\mathrm{i}}$ pathways. This involves both constitutive and agonist-mediated signalling, and association between GHSR1a and $\beta$-arrestins may increase RhoA pathways. (A) Interaction with MRAP2 impairs GHSR1a constitutive activity and $\beta$-arrestin recruitment, and biases signalling towards enhanced agonist-mediated $\mathrm{Ca}^{2+}{ }_{j}$ signalling. (B) Interactions between $\mathrm{GHSR} 1 \mathrm{a}$ and $\mathrm{MC} 3 \mathrm{R}$ enhance MC3R-mediated $\mathrm{G}_{\mathrm{s}}$-CAMP signalling and impair ghrelin-mediated increases in $\mathrm{Ca}^{2+}$. Similar mechanisms are observed for $\mathrm{GPR} 83$, 5-HT ${ }_{2} \mathrm{R}_{\text {, }}$ and $\sigma 1 R$. (C) Interactions between GHSR1a and OX1R switch $\mathrm{G}$ protein coupling from $\mathrm{G}_{\mathrm{q}}$ to $\mathrm{G}_{\mathrm{s}}$. Interactions with GHSR1b and SSTR2 also result in a switch in $\mathrm{G}$ protein coupling that is governed by the stoichiometry of each receptor. In the presence of high GHSR1b expression, the inactive receptor exerts a dominant-negative effect on GHSR1a-mediated signalling. When GHSR1b expression is low, as in hippocampal and striatal neurons, GHSR1a interacts with both GHSR1b and DRD1 to activate $\mathrm{G}_{\mathrm{s}}$-CAMP signalling. (D) Interactions between GHSR1a and DRD2 and DRD1 result in reciprocal increases in signalling by both receptors. (E) Interactions with prostanoid receptors impair GHSR1a constitutive signalling. AGRP, agouti-related peptide; Ca2+ ${ }_{i}$, intracellular $\mathrm{Ca}_{2+}^{2}$; DRD1, dopamine receptor D1; DRD2, dopamine receptor D2; EP3-I, prostaglandin $\mathrm{E}_{2}$ receptor subtype $\mathrm{EP}_{3-\text {; }}$ GHSR1, growth hormone secretagogue receptor; GPR83, G protein-coupled receptor-83; MC3R, melanocortin-3 receptor; MRAP2, melanocortin receptor accessory protein-2; OX1R, orexin-1 receptor; $\mathrm{TP} \alpha$, thromboxane prostanoid $\mathrm{A} 2$ receptor; $5-\mathrm{HT}_{2} \mathrm{R}$, serotonin (5-hydroxytryptamine) subtype-2C receptor; $\sigma 1 \mathrm{R}$; neuronal sigma-1 receptor.

https://joe.bioscientifica.com https://doi.org/10.1530/JOE-21-0206 (c) 2021 The authors Published by Bioscientifica Ltd. Printed in Great Britain

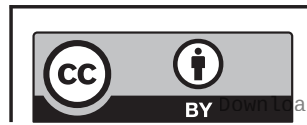

This work is licensed under a Creative Commons Attribution 4.0 International License. 


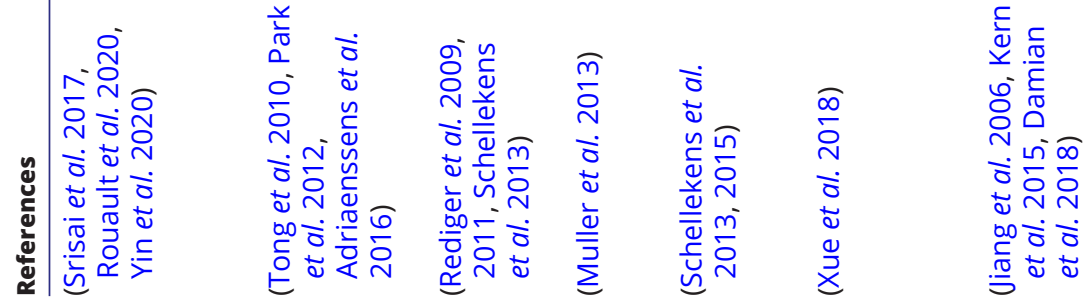

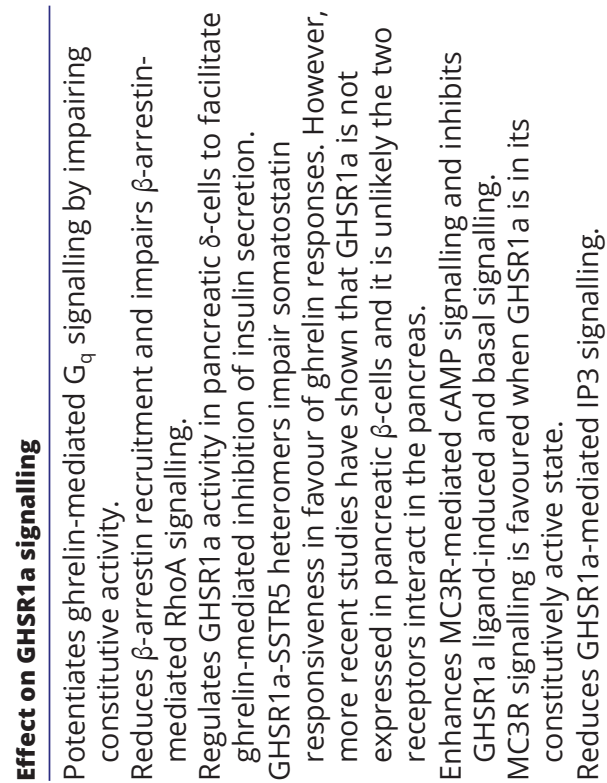

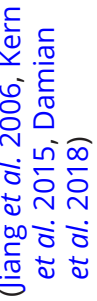

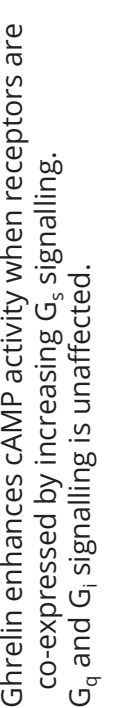

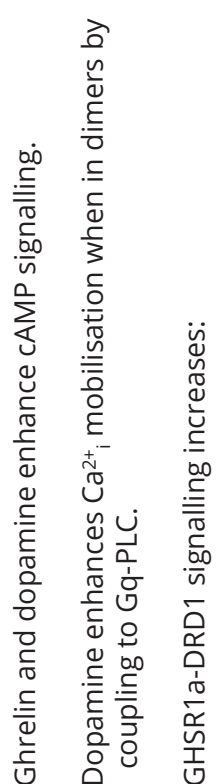

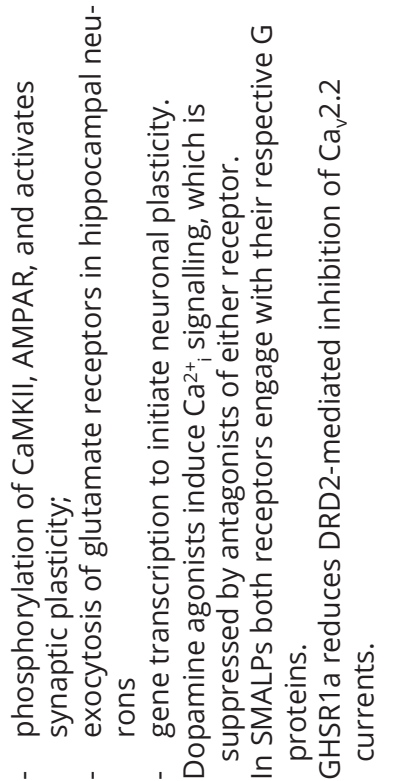

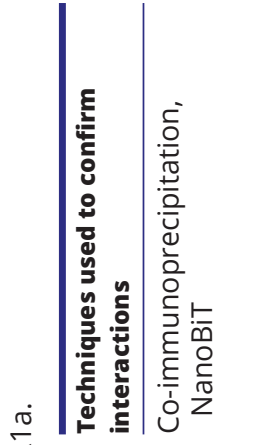
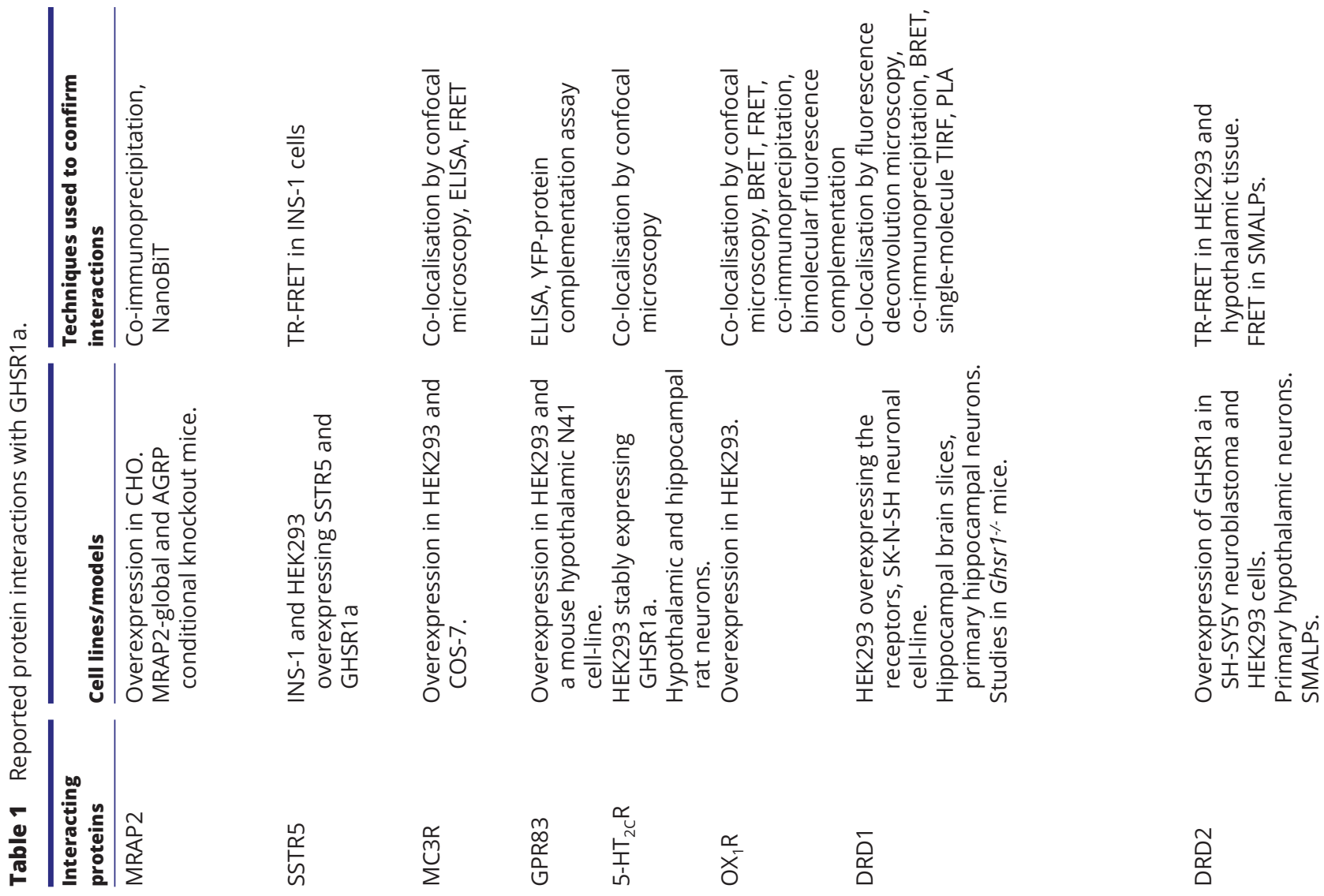

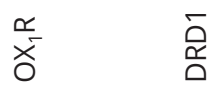

กิ 


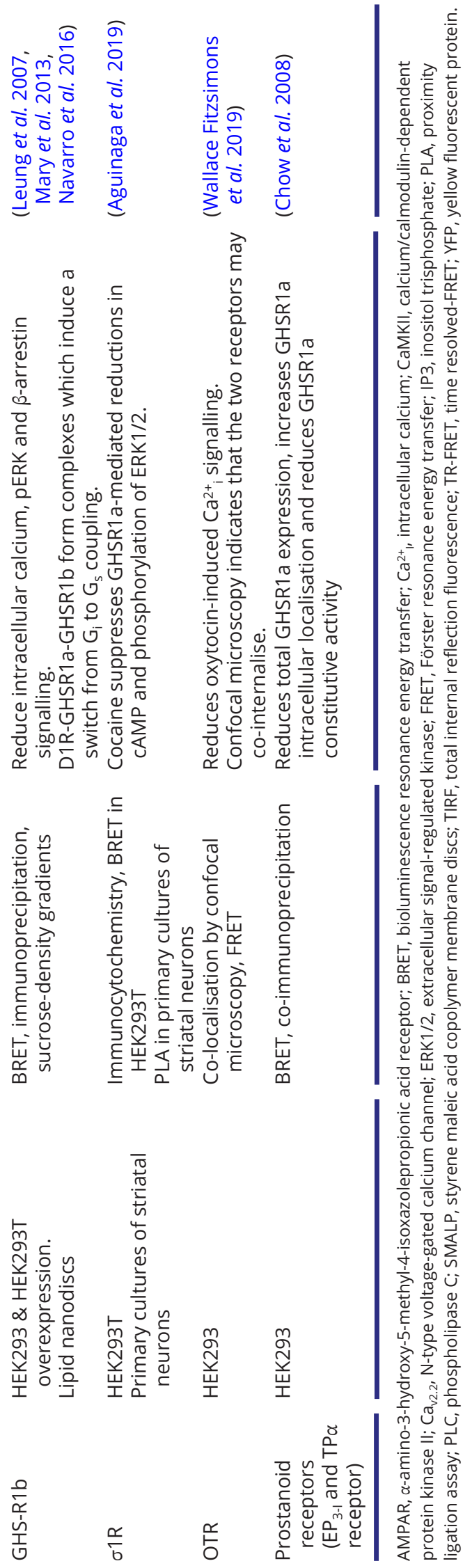

https://joe.bioscientifica.com https://doi.org/10.1530/JOE-21-0206 (c) 2021 The authors Published by Bioscientifica Ltd. Printed in Great Britain
(Rouault et al. 2020). MRAP2 reduced $\beta$-arrestin recruitment in NanoBiT assays and impaired $\beta$-arrestin-mediated RhoA signalling (Rouault et al. 2020). Thus, MRAP2 elicits signalling bias upon the GHSR1a, by enhancing $G_{q / 11}$ signalling and reducing $\beta$-arrestin pathways (Fig. 1).

These studies indicate that compounds that disrupt the GHSR1a and MRAP2 interaction sites, may be more effective in reducing food intake than those targeting GHSR1a alone. Modifying MRAP2 abundance would be unlikely to be effective, as MRAP2 regulates other GPCRs. The finding that GHSR1a constitutive activity is lost upon interaction with MRAP2 implies that GHSR1a agonistindependent signalling may not be physiologically relevant, at least in cells expressing MRAP2. A number of previous studies have provided evidence that GHSR1a constitutive activity has a physiological function; however, interpretation of some of these data can be problematic as some GHSR1a-targeting compounds and receptor mutations that impair constitutive activity also affect agonist-driven activity. GHSR inverse agonists inhibit constitutive activity, reduce food intake and body weight in rats, and decrease compensatory hyperphagia following a fast in mice (Petersen et al. 2009, Fernandez et al. 2018). However, these compounds may also elicit antagonistic properties and therefore the interpretation of their effects is problematic. Moreover, a number of studies have investigated the GHSR1a-A204E variant, which has a loss of constitutive activity in vitro, and has been identified in patients with short stature and obesity (Pantel et al. 2006). Although this mutation abolishes constitutive activity, reduces body length, and impairs GH release in mice with the equivalent A203E mutation, agonist-mediated activity was also impaired in these models, implying that the phenotypes observed in human carriers of the GHSR1aA204E mutation cannot be attributed solely to defective constitutive activity (Torz et al. 2020). Similarly, studies of the GHSR1a-A204E mutation with MRAP2 showed loss of constitutive activity but also reduced ghrelinmediated responses, and structural studies suggest A204 may regulate ghrelin's access to binding cavities (Rouault et al. 2020, Shiimura et al. 2020). Thus, studies with A204E should be interpreted cautiously, as the mutation also impairs ghrelin-mediated activity. Further studies are likely required to determine the physiological role of GHSR1a basal activity in the regulation of energy metabolism.

MRAP2 has also been shown to regulate GHSR1a in pancreatic islets (Yin et al. 2020). Ghrelin is known to exert acute inhibition on insulin release and impair glucose tolerance in humans and rodents (Tong et al. 2010, Adriaenssens et al. 2016). Early studies indicated that

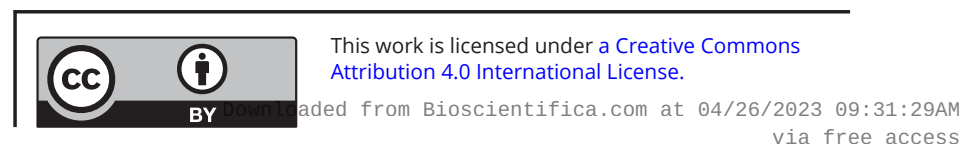


Table 2 Summary of studies in which GHSR1a interactions with transmembrane proteins have been investigated in physiological systems.

\section{Interacting}

proteins

MRAP2

Cell lines/models

In MRAP2-knockout mice:

ghrelin-induced AMPK phosphorylation and cFos activity are reduced ghrelin-mediated increases in food intake are absent

In AGRP-neuron conditional MRAP2 knockout mice:

- GCamp6 calcium oscillations are impaired in AGRP neurons

In conditional mice with deletion of MRAP2 from somatostatin-secreting cells:

- ghrelin-mediated inhibition of insulin secretion is abolished.

GPR83 - Acute food intake is significantly higher in Gpr83-1- mice following a single ghrelin injection.

- Twice-daily ghrelin treatment of high-fat-diet fed mice for 6 days showed a greater increase in food intake in Gpr83-/- mice.

- Gpr83-/- mice had increased body weight, food intake, and fat mass following ghrelin infusion when fed regular chow.

$5-\mathrm{HT}_{2} \mathrm{R}$ - Administration of a $5-\mathrm{HT}_{2} \mathrm{R}$ antagonist enhanced ghrelin-induced increases in food intake, and extended the duration of ghrelin's orexigenic effect.

- Administration of lorcaserin delayed ghrelin-induced effects on food intake.

DRD1 Ghsr-/- hippocampal slices showed GHSR1a-DRD1 signalling is required for:

- phosphorylation of CaMKII, AMPAR

- activation of synaptic plasticity;

- exocytosis of glutamate receptors in hippocampal neurons;

- gene transcription for initiation of neuronal plasticity.

Behavioural studies showed:

- DRD1-selective agonists disrupted prepulse inhibition. Prepulse inhibition is disrupted in $\mathrm{Ghsr}^{+/+}$but not $\mathrm{Ghsr}^{-/-}$mice when pre-injected with a DRD1 agonist.

- Mice treated with DRD1-specific agonist SKF81297 had a significant decrease in freezing behaviour in contextual and cued-fear conditioning apparatus, which was impaired by co-administration with a GHSR1a antagonist.

- Mice infused with SKF81297 continued to make correct choices in a T-maze alternation test, which was blocked by co-administration with a GHSR1a antagonist, consistent with enhanced memory when GHSR1a-DRD1 heteromers are activated.

In GHSR1a-null, 5xFAD and double mutant GHSR1a-null/5xFAD mice there were:

- similar reductions in synapse density;

- impaired stimulus-evoked LTP in hippocampal slices;

- impaired spatial navigation in the Morris water maze test, indicating that the same pathways are affected in mice.

Restoration of GHSR1a-DRD1 complexes, by simultaneous stimulation of GHSR1a and DRD1 with MK0677 and SKF81297:

- increased synaptic density in Aß42-treated mouse hippocampal neurons;

- improved stimulus-evoked LTP, and restored miniature excitatory postsynaptic current frequency in 5xFAD mice;

- reversed memory defects in the Morris water maze test and reduced hippocampal synapse loss in 5xFAD mice.

DRD2 - Agonists of DRD2 and GHSR1a stimulated calcium in primary hypothalamic neurons.

- The DRD2 selective agonist cabergoline suppressed food intake in WT mice.

- Pre-treatment with the GHSR1a antagonist JMV2959 prevented the cabergoline effect on food intake.

GHS-R1b In striatal neurons - a DRD1 antagonist blocked ghrelin-induced Gs-mediated cAMP accumulation.

o1R In primary striatal neurons - impaired GHSR1a-mediated signalling on pre-treatment with cocaine or PRE-084.

\section{References}

(Srisai et al. 2017, Yin

et al. 2020)

(Muller et al. 2013)

(Schellekens et al. 2015)

(Kern et al. 2015)

(Kern et al. 2012)

(Navarro et al. 2016)

(Aguinaga et al. 2019)

AGRP, agouti-related peptide; AMPAR, $\alpha$-amino-3-hydroxy-5-methyl-4-isoxazolepropionic acid receptor; AMPK, AMP-activated protein kinase; CaMKII, calcium/calmodulin-dependent protein kinase II; LTP, long-term potentiation.

https://joe.bioscientifica.com https://doi.org/10.1530/JOE-21-0206 (c) 2021 The authors Published by Bioscientifica Ltd. Printed in Great Britain

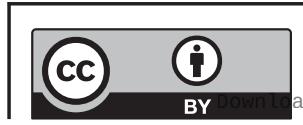

This work is licensed under a Creative Commons Attribution 4.0 International License.

ded from Bioscientifica com at 04/26/2023 09:31:29AM 
GHSR1a may be expressed on both human pancreatic $\alpha$-and $\beta$-cells, and that the receptor suppresses insulin secretion by coupling to $G_{i / o}$ signalling pathways, rather than canonical $\mathrm{G}_{\mathrm{q}}$ pathways (Dezaki et al. 2007). This $\mathrm{G}$ protein switching in pancreatic $\beta$-cells was hypothesised to occur via dimerisation between GHSR1a and the somatostatin receptor subtype-5 (SSTR5), and studies in transfected INS-1 cells provided evidence for interaction between the two receptors (using time-resolved FRET (TR-FRET)) and cross-talk between the receptor's signalling pathways (Park et al. 2012). However, more recent RNA-seq studies have shown that GHSR1a is exclusively expressed in pancreatic $\delta$-cells (Adriaenssens et al. 2016, DiGruccio et al. 2016). These later studies have shown that ghrelin activation of GHSR1a on $\delta$-cells triggers somatostatin release, which subsequently inhibits $\beta$-cells by activation of $\mathrm{G}_{\mathrm{i} / \mathrm{o}}$-coupled SSTRs (Adriaenssens et al. 2016, DiGruccio et al. 2016). Furthermore, ghrelin infusion of mouse pancreases still stimulated somatostatin secretion in the presence of inhibitors of SSTR2, 3, and 5, but abolished insulin and glucagon release, demonstrating ghrelin actions upon somatostatin are unlikely to occur via direct coupling between the two receptors (Adriaenssens et al. 2016). In contrast, deletion of MRAP2 from pancreatic somatostatinexpressing cells of mice prevents the ghrelin-mediated inhibition of insulin secretion, indicating MRAP2 likely directly regulates GHSR1a activity in pancreatic $\delta$-cells (Yin et al. 2020). These studies highlight the importance of in vivo verification of GHSR1a interactions identified in cell models.

\section{GHSR1a interaction with melanocortin-3 receptor (MC3R)}

MC3R is a GPCR expressed on both pro-opiomelanocortin and AGRP neurons of the hypothalamus, where it has a role in maintaining homeostatic energy set-points, by controlling responses to both calorie restriction and calorierich diet (Ghamari-Langroudi et al. 2018). Thus, MC3R and GHSR1a share roles in monitoring and maintaining energy balance. When co-transfected in HEK293 cells, GHSR1a and MC3R colocalised, and may internalise together (Rediger et al. 2009, Schellekens et al. 2013). The two receptors are located within close proximity when overexpressed in COS-7 and HEK293 cells, shown by ELISA and Förster resonance energy transfer (FRET), respectively (Rediger et al. 2009). In situ hybridisation in mouse hypothalamic brain slices showed that the majority of GHSR-expressing neurons in the arcuate nucleus also express MC3R, but reciprocally, not all MC3R-expressing neurons express GHSR1a (Rediger et al. 2011). Heterodimerisation of the two receptors leads to enhancement of MC3R ligand-induced signalling, shown by increased cAMP accumulation, and inhibition of GHSR1a ligand-induced and basal signalling, shown by reduced inositol phosphate (IP) accumulation in COS-7 cells co-transfected with the two receptors (Rediger et al. 2011) (Fig. 1). Replication of these studies using a series of receptor mutants showed that dimerisation still occurs, but hyperstimulation of Gs in heterodimers is lost when either a loss-of-function MC3R mutant (Ile183Asn) or mutant GHSR1a with partial loss of constitutive activity (Ala204Glu, Phe279Leu) are introduced (Rediger et al. 2011). Moreover, the GHSR1a inverse agonist substance $P$ reduced maximal MC3R cAMP.

These studies indicate that functional MC3R is absolutely required for enhanced cAMP signalling from heterodimers, and that the structure of the GHSR1a, when in the constitutively active state, favours MC3R signalling. Therefore, within these heterodimers GHSR1a must adopt a structural conformation that mediates constitutive activity but has reduced capacity to bind ghrelin, or impaired $\mathrm{G} \alpha$ coupling and/or activation. Investigation of how GHSR1aMC3R heterodimers interact with G proteins could reveal further insights into how MC3R signalling is enhanced. MC3R heterodimerisation with GHSR1a could be one mechanism by which hypothalamic neurons exert the balance between orexigenic and anorexigenic signals. In a high energy state, heterodimer formation may be favoured, suppressing GHSR1a and increasing MC3R signalling, while low energy states may favour monomers, allowing GHSR1a signalling to proceed. Further investigation in physiologically relevant cells will be required to verify this.

\section{GHSR1a interaction with G protein-coupled receptor-83 (GPR83)}

Interaction between GPR83 and the GHSR1a was shown in 2013, several years before the natural agonist of GPR83 was identified (Muller et al. 2013). Studies showed that GPR83 was concentrated within arcuate neurons expressing AGRP and GHSR1a, and that its expression was regulated by nutrient availability, indicating a possible role in appetite regulation (Muller et al. 2013). A neuropeptide designated PEN, which is produced from the proSAAS precursor protein, was identified in 2016 as a ligand for GPR83 (Gomes et al. 2016). Mice overexpressing proSAAS develop obesity, while proSAAS-null mice exhibit reduced body weight, and antibody-mediated neutralisation of

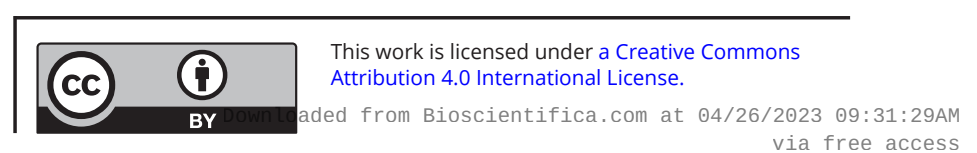


endogenous PEN reduces food intake in mice (Morgan et al. 2010, Gomes et al. 2016). Gpr83-/- mice had normal body weight, food intake, and insulin sensitivity when fed a regular diet; but decreased free-fatty acids, body fat mass, and plasma leptin levels compared to controls, indicating GPR83 may be involved in regulating lipolysis (Muller et al. 2013). Moreover, GPR83-/- elicited enhanced reward behaviours (preference for sucrose) and attenuation of stress-evoked anxiety.

Heterodimerisation between GHSR1a and GPR83 was shown in HEK293 cells and a mouse hypothalamic N41 cell-line overexpressing the receptors using ELISA and yellow fluorescent protein-based protein complementation assays. Moreover, co-transfection of cells with these receptors reduced ghrelin-mediated inositol trisphosphate (IP3), indicating that GPR83 may inhibit GHSR1a signalling (Muller et al. 2013). Acute food intake was significantly higher in Gpr83-/- mice, when compared to WT littermates, following a single intraperitoneal injection of ghrelin; while twice-daily s.c. ghrelin treatment of high-fat diet-fed mice for 6 days showed a greater increase in food intake in $\mathrm{Gpr} 83^{-/-}$mice. Gpr83-/- mice had increased body weight, food intake, and fat mass following ghrelin infusion when fed regular chow. Therefore, these studies provide evidence that GPR83 may influence GHSR1a-mediated signalling and physiological function. However, Gpr83-/- mice were protected from diet-induced obesity and glucose intolerance, and plasma levels of acyl-ghrelin and desacyl-ghrelin were unaffected when fed a high-fat diet for 18 weeks, indicating that GPR83 likely has ghrelinindependent roles in appetite regulation.

These studies suggest an interplay between GPR83 and GHSR1a in vivo. However, it is unclear whether heterodimerisation is responsible for these physiological effects as dimers were only shown in transfected cells overexpressing receptors, and thus it is unclear if these heterodimers form in real tissues; further studies may be required to investigate this. Additionally, interpretation of the data is complicated by the overlap between physiological functions, the shared signalling pathways of GPR83 and GHSR1a (both signal by $\mathrm{G}_{\mathrm{q}}$ and reduced activation could be due to competition for $G$ proteins and downstream mediators), and evidence that both receptors form heteromers with other GPCRs (including both with MC3R). Further studies of GPR83-GHSR1a heterodimers with ligands for both receptors and investigation of signalling by endogenous receptors could reveal further insights into how these receptors regulate food intake.

\section{GHSR1a interaction with serotonin (5-hydroxytryptamine, 5-HT) subtype-2C receptor $\left(5-\mathrm{HT}_{2 \mathrm{C}} \mathrm{R}\right)$}

The anorexigenic effect of 5-HT on the brain has been known since the 1970s and considerable effort has been made to develop compounds that can act as agonists on 5-HT receptors, with lorcaserin, a selective $5-\mathrm{HT}_{2 \mathrm{C}} \mathrm{R}$ agonist, approved by the Food and Drug Administration for use in obesity. Several lines of evidence indicate crosstalk between serotonin- and ghrelin-mediated signalling within neurons. In mice, fasting induces an increase in expression of the $5-\mathrm{HT}_{2 \mathrm{C}} \mathrm{R}$ and $5-\mathrm{HT}_{1 \mathrm{~B}} \mathrm{R}$ genes alongside increases in plasma active ghrelin compared to the fed state; 5-HT receptor agonists (meta-chlorophenylpiperazine and fenfluramine) inhibit the increase in plasma active ghrelin in mice; ghrelin inhibits serotonin release in rat hypothalamic synaptosomes; and administration of the 5- $\mathrm{HT}_{2 \mathrm{C}} \mathrm{R}$ agonist 5-dimethoxy-4-iodoamphetamine, attenuates ghrelin-induced food intake in rats (Brunetti et al. 2002, Nonogaki et al. 2006, Currie et al. 2010).

Both in vitro and in vivo studies have investigated heterodimerisation between $5-\mathrm{HT}_{2 \mathrm{C}} \mathrm{R}$ and GHSR1a. Initial studies using confocal microscopy showed co-localisation of overexpressed 5- $\mathrm{HT}_{2 \mathrm{C}} \mathrm{R}$ with GHSR1a in HEK293 cells, and demonstrated that receptors co-internalise, which was enhanced by treatment with ghrelin, but not with MK0677 and 5-HT (Schellekens et al. 2013). GHSR1a and $5-\mathrm{HT}_{2 \mathrm{C}} \mathrm{R}$ primarily couple to $\mathrm{G}_{\mathrm{q}}$, complicating studies of heterodimerisation as effects on signalling could be caused by competition between receptors for downstream signal partners. Studies showed that the dose-dependent maximal ghrelin-induced calcium influx was lower in cells which co-express $5-\mathrm{HT}_{2 \mathrm{C}} \mathrm{R}$ and GHSR1a, compared to cells that expressed only GHSR1a, and that treatment with the 5- $\mathrm{HT}_{2 \mathrm{C}}$ receptor-specific antagonist (RS102221) fully restored maximal ghrelin and MK0677-induced calcium influx to levels observed in cells transfected with just GHSR1a (Schellekens et al. 2013).

In a subsequent study from the same research group, co-localisation between $5-\mathrm{HT}_{2 \mathrm{C}} \mathrm{R}$ and fluorescein-ghrelin was shown in a subset of hypothalamic and hippocampal rat neurons, demonstrating heterodimerisation or receptor cross-talk could be possible in these neurons (Schellekens et al. 2015). Investigations in mice showed that administration of a $5-\mathrm{HT}_{2 \mathrm{C}} \mathrm{R}$ antagonist (SB242084) enhanced ghrelin-induced increases in food intake and extended the duration of ghrelin's orexigenic effect. Moreover, administration of lorcaserin delayed ghrelininduced effects on food intake (Schellekens et al. 2015).

This work is licensed under a Creative Commons Attribution 4.0 International License.

ed from Bioscientifica.com at 04/26/2023 09:31:29AM 
These studies, demonstrating $5-\mathrm{HT}_{2 \mathrm{C}} \mathrm{R}$ antagonism results in a long-lasting orexigenic effect, indicate that therapeutic targeting of heterodimers may be useful to increase appetite and food intake, and could potentially be used in the treatment of anorexia nervosa; while conversely, combinations of $5-\mathrm{HT}_{2 \mathrm{C}} \mathrm{R}$ agonists with GHSR1a antagonists could reduce appetite, with possible utility for anti-obesity therapies. Further work investigating the effect of $5-\mathrm{HT}_{2 \mathrm{C}} \mathrm{R}$ agonism/antagonism on ghrelin-mediated signalling is required in animal models to investigate the long-term effects on food intake and energy metabolism. Furthermore, as the evidence for heterodimerisation is based entirely on overexpression in cell lines, with comparisons made to single transfected cells, further evidence is required to determine whether the physiological effects observed are due to receptor heterodimerisation or signal pathway cross-talk.

\section{GHSR1a interaction with the orexin-1 receptor $\left(\mathrm{OX}_{1} \mathrm{R}\right)$}

Orexin-A and orexin-B are neuropeptides encoded by a single precursor protein, pre-pro-orexin, produced in the lateral hypothalamus, that activate the orexin-1 and orexin- $2 \mathrm{G} \alpha_{\mathrm{q}}$-coupled receptors $\left(\mathrm{OX}_{1} \mathrm{R}\right.$ and $\mathrm{OX}_{2} \mathrm{R}$, respectively). The orexins act upon receptors expressed in the prefrontal and infralimbic cortex, hippocampus, hypothalamic nuclei, dorsal raphe nucleus, ventral tegmental area, and locus coeruleus where they regulate functions including sleep and wakefulness, feeding and energy expenditure, and reward (Inutsuka et al. 2014, Muschamp et al. 2014).

A single study described dimerisation between $\mathrm{OX}_{1} \mathrm{R}$ and GHSR1a when overexpressed in HEK293 cells (Xue et al. 2018). Co-localisation of the receptors and close proximity were shown using bioluminescence resonance energy transfer (BRET), FRET, co-immunoprecipitation, and bimolecular fluorescence complementation (BiFC) (Xue et al. 2018). Ghrelin enhanced cAMP activity (assessed using ELISA, exchange proteins directly activated by cAMP (EPAC) biosensor, and cAMP response element (CRE) luciferase reporter assays) in cells co-expressing GHSR1a and $\mathrm{OX}_{1} \mathrm{R}$, compared to cells expressing either receptor alone (Xue et al. 2018). Orexin-A was unable to induce increased signalling in cells expressing both receptors. BRET assays examining $\mathrm{G} \alpha$ protein interaction with GHSR1a and OX1R dimers showed enhanced BRET ratios when $G \alpha_{s}$ was stimulated by ghrelin, compared to co-expressed cells stimulated with orexin, and cells expressing either receptor alone. In contrast, $\mathrm{Ca}^{2+}{ }_{\mathrm{i}}$, serum-response element luciferase reporter activity, and BRET ratios with $\mathrm{G} \alpha_{\mathrm{q}}$ and $\mathrm{G} \alpha_{\mathrm{i}}$ were unchanged in cells co-expressing GHSR1a and $\mathrm{OX}_{1} \mathrm{R}$ (Xue et al. 2018). The authors concluded that GHSR $1 \mathrm{a}-\mathrm{OX}_{1} \mathrm{R}$ heterodimers favour coupling to $\mathrm{G} \alpha_{\mathrm{s}}$, rather than $\mathrm{G} \alpha_{\mathrm{q}}$ that is utilised by each receptor when expressed alone (Fig. 1).

These studies demonstrated that co-expression of GHSR1a and $\mathrm{OX}_{1} \mathrm{R}$ may allow the receptors to activate novel signalling pathways. It could be hypothesised that this may affect stress responses, food intake, energy homeostasis, and reward behaviours, all of which have been shown to be influenced by ghrelin and orexin. Moreover, MRAP2, which enhances GHSR1a activity in the hypothalamus, negatively regulates $\mathrm{OX}_{1} \mathrm{R}$ (Rouault et al. 2017). Therefore, it is possible that MRAP2 could influence signalling by GHSR1a-OX1R dimers. However, heterodimerisation between GHSR1a and $\mathrm{OX}_{1} \mathrm{R}$ was only demonstrated in cells overexpressing the receptors, and therefore the physiological relevance of these findings remain to be demonstrated in neuronal cells and/or animal models.

\section{GHSR1a interaction with dopamine receptor D1 (DRD1)}

GHSR1a has been reported to associate with two dopamine receptors: DRD1 (see GHSR1a interaction with dopamine receptor D2 (DRD2)), which is co-expressed with GHSR1a at the hippocampus, midbrain, substantia nigra, and ventral tegmental areas (Jiang et al. 2006); and DRD2, which is co-expressed with GHSR1a at the hypothalamus (Kern et al. 2012). DRD1 is a $\mathrm{G}_{\mathrm{s}}$-coupled receptor which regulates neuronal growth and development, learning and memory, and reward behaviours. Neuromodulation of dopamine signalling by ghrelin was proposed as ghrelin administration to rats dose-dependently augments cocaine-induced hyperactivity, a pathway known to involve dopamine signalling (Wellman et al. 2005). Initial studies showed co-treatment of cells overexpressing GHSR1a and DRD1 with dopamine and ghrelin enhanced cAMP signalling by three- to four-fold when compared to cells treated with DRD1 alone (Jiang et al. 2006) (Fig. 1). However, dopamine had no effect on ghrelin pathways, measured by aequorin $\mathrm{Ca}^{2+}{ }_{\mathrm{i}}$ signalling. Three methods were used to provide evidence of GHSR1aDRD1 heteromer formation: co-localisation using fluorescence deconvolution microscopy in a neuronal cell-line (SK-N-SH), immunoprecipitation in lysates from transfected HEK293 cells, and BRET studies which showed

This work is licensed under a Creative Commons Attribution 4.0 International License.

ded from Bioscientifica.com at 04/26/2023 09:31:29AM 
enhanced proximity between the receptors when cells were incubated with dopamine and ghrelin (Jiang et al. 2006).

The presence of GHSR1a and DRD1 complexes was confirmed in hippocampal brain slices using FITC-labelled ghrelin and a fluorescent DRD1 antagonist (red-SKF83566). The real-time dynamics of DRD1 and GHSR1a interactions were explored in primary hippocampal neuronal cultures using single-molecule total-internal reflection fluorescence microscopy (labelling endogenous proteins). GHSR1a and DRD1 co-localised in membranes, had significantly slower diffusion within complexes, and co-localisation increased in the presence of a DRD1-specific agonist (SKF81297) (Kern et al. 2015). In contrast to previous studies (Jiang et al. 2006), SKF81297 was shown to dose-dependently induce rapid $\mathrm{Ca}^{2+}{ }_{\mathrm{i}}$ transients in hippocampal brain slices (measured using the $\mathrm{Ca}^{2+}$ sensor GCaMP3), which were absent from Ghsr1-/- mice. Moreover, pre-treatment of hippocampal slices with the GHSR1a antagonist JMV2959 blocked SKF81297-induced $\mathrm{Ca}^{2+}{ }_{\mathrm{i}}$ mobilisation (Kern et al. 2015). Dopamine-induced $\mathrm{Ca}^{2+}{ }_{\mathrm{i}}$ mobilisation was not dependent on signalling by $\mathrm{G} \alpha_{s}$, adenylyl cyclase-protein kinase $A, G \alpha_{i} / o-G \beta \gamma$, or protein kinase $C$, but did require PLC; and GHSR1a constitutive activity was not required as GHSR1a-F279L and -A204E did not prevent DRD1 noncanonical signalling (Kern et al. 2015). GHSR1a fusion proteins containing inducible homodimerisation domains showed that enhanced GHSR1a homodimerisation (and thus reduced GHSR1a availability to form GHSR1a-DRD1 heterodimers) correlated with reduced dopamine-induced $\mathrm{Ca}^{2+}{ }_{1}$ mobilisation. Moreover, BRET assays measuring $\mathrm{G}_{\mathrm{q}}{ }^{-}$ G $\beta \gamma$ in HEK293 cells overexpressing GHSR1a and DRD1 showed that SKF81297 attenuated signalling, consistent with DRD1 pre-coupling to $G \alpha_{\mathrm{q}}$ and agonist-induced dissociation of the heterotrimeric $G$ protein complex; while pre-treatment with JMV2959 dose-dependently inhibited the SKF81297-induced decrease in BRET, indicating that GHSR1a is involved in the DRD1-G $\alpha_{q}$ coupling. Dopamineinduced $\mathrm{Ca}^{2+}{ }_{i}$ activation was retained, but reduced, when DRD1 was expressed with GHSR1a mutants unable to couple to $\mathrm{G} \alpha_{\mathrm{q}}$ (due to mutations in the third intracellular loop), confirming direct coupling of DRD1 to $G \alpha_{\mathrm{q}}$ (Kern et al. 2015).

A series of studies showed that GHSR1a is fundamentally important for DRD1-induced initiation of hippocampal synaptic plasticity and formation of hippocampal memory. Initially, phosphorylation of $\mathrm{Ca}^{2+} / \mathrm{calm}_{\text {modulin-dependent }}$ protein kinase II and its target, the GluR1 subunit of $\alpha$-amino-3-hydroxy-5-methyl-4-isoxazolepropionic acid receptor, which are involved in activation of synaptic plasticity, were shown to be activated at synapses by DRD1 activation. Phosphorylation of these proteins was lost in Ghsr-/- hippocampal slices. Next, exocytosis of glutamate receptors in hippocampal neurons was shown to be dependent on GHSR1a-DRD1 signalling. The transcription of genes involved in initiation of neuronal plasticity was also dependent on GHSR1a in hippocampal slices. Moreover, behavioural studies in mice showed: (i) DRD1induced interference with prepulse inhibition, a measure of how well an animal can integrate and inhibit sensory information, is dependent on GHSR1a; (ii) Mice treated with SKF81297 exhibited a significant decrease in freezing behaviour in contextual and cued-fear conditioning apparatus, which was impaired when co-administered with JMV2959, consistent with allosteric interactions between GHSR1a and DRD1 in memory; and (iii) mice infused with SKF81297 continued to make correct choices in a T-maze alternation test, which was blocked by co-administration with JMV2959, consistent with enhanced memory when GHSR1a-DRD1 heteromers are activated (Kern et al. 2015).

Recently, a reduction in GHSR1a-DRD1 complexes in favour of establishment of GHSR1a-A $\beta$ complexes was shown to correlate with Alzheimer's disease (Tian et al. 2019). GHSR1a is overexpressed in hippocampal tissue from Alzheimer's disease patients, and in the brains of $5 \mathrm{xFAD}$ mice, a model for the disease. This is particularly apparent in aged mice with heavy brain amyloidopathy with severe hippocampal lesions, in which GHSR1a forms complexes with amyloid beta $(\mathrm{A} \beta$, the plaque deposits that are a hallmark of Alzheimer's disease pathology), shown by proximity ligation assay (PLA). GHSR1a activity assays using fluorescein arsenical hairpin binder-based FRET in HEK293T cells showed $A \beta$ has an antagonist-like effect on MK0677-mediated GHSR1a responses, and reduced GHSR1a-DRD1 complex formation (Tian et al. 2019). In GHSR1a-null, 5xFAD and double mutant GHSR1anull/5xFAD mice there were similar reductions in synapse density, impaired stimulus-evoked LTP in hippocampal slices, and impaired spatial navigation in the Morris water maze test, indicating that the same pathways are affected in mice. Restoration of GHSR1a-DRD1 complexes, by simultaneous stimulation of GHSR1a and DRD1 with MK0677 and SKF81297 increased synaptic density in A $\beta 42$-treated mouse hippocampal neurons; improved stimulus-evoked LTP, and restored miniature excitatory postsynaptic current frequency in 5xFAD mice; reversed memory defects in the Morris water maze test and reduced hippocampal synapse loss in 5xFAD mice (Damian et al. 2018). Thus, these studies demonstrate that disruption of GHSR1a-DRD1 complexes contributes to the synaptic abnormalities and behavioural impairments in mouse

This work is licensed under a Creative Commons Attribution 4.0 International License. ed from Bioscientifica.com at 04/26/2023 09:31:29AM 
models of Alzheimer's disease. The ability to rescue these complexes in hippocampal tissue, with consequent prolonged functionality, indicates that co-stimulation of GHSR1a-DRD1 could be an important preventative treatment for Alzheimer's disease.

\section{GHSR1a interaction with dopamine receptor D2 (DRD2)}

DRD2 is coupled to $\mathrm{G}_{\mathrm{i} / \mathrm{o}}$ signalling pathways and hypothalamic dopamine signalling is important for basal regulation of food intake by influencing feeding frequency and volume (Meguid et al. 2000). DRD2 is reduced in the striatum of obese rats (which correlates with addictive behaviours), and knockdown of the receptor in rat striatum accelerates the onset of compulsive-like food seeking in rats with access to palatable high-fat food (Johnson \& Kenny 2010).

Interactions between DRD2 and GHSR1a were first investigated in SH-SY5Y neuroblastoma cells stably overexpressing GHSR1a (SH-GHSR1). In contrast to native cells, in which activation of DRD2 with the selective agonist quinpirole induced $G_{\mathrm{i}}$ signalling and was not linked to calcium; SH-GHSR1 cells produced a dosedependent increase in calcium, which was attenuated by the DRD2 antagonist raclopride and GHSR1a inverse agonist substance P. Quinpirole and ghrelin stimulation of calcium was also observed in primary hypothalamic neurons and HEK293 cells co-expressing the two receptors (Kern et al. 2012). Further studies in HEK293 cells with a range of inhibitors showed that these responses were mediated by $\mathrm{G}_{\mathrm{i} / 0}$-PLC-IP3-Ca ${ }^{2+}{ }_{\mathrm{i}}$ pathways, which likely involve direct association between G $\beta \gamma$ and GPCR kinase-2 (GRK2) (Kern et al. 2012). Co-expression of DRD2 with GHSR1a mutants that have low basal activity (F279L) showed dopamine could induce partial signalling, indicating that basal activity is unlikely to play a role, and that allosteric interactions between GHSR1a and DRD2 are likely more important (Kern et al. 2012). Heteromerisation was shown by TR-FRET in HEK293 cells and hypothalamic tissue, and cross-desensitisation, in which pre-treatment of cells with increasing concentrations of GHSR1a agonists MK0677 and ghrelin, or with DRD2 agonists dopamine or quinpirole, reduced dopamine-induced or ghrelin-induced calcium mobilisation, respectively. Additional evidence of DRD2-GHSR1a interactions were shown in animal models in which the DRD2 selective agonist cabergoline suppressed food intake in WT mice, whereas food intake in Ghsr1-/- mice was unaffected. Pre-treatment with a
GHSR1a antagonist JMV2959 prevented the cabergoline effect on food intake (Kern et al. 2012).

A subsequent study investigated how GHSR1a and DRD2 oligomerise in styrene maleic acid copolymer membrane discs (SMALPs). SMALPs allow detergent-free solubilisation of membrane proteins within their native bilayer environment, which stabilises the extracted proteins (Dorr et al. 2016). Two- and three-colour FRET was used to show that heteromers contain two GHSR1a and two DRD2 protomers. Both receptors are associated with their respective $G$ protein in these complexes, and $\mathrm{G}_{\mathrm{i}}$ activation was more efficient in GHSR1a-DRD2 heteromers, and impaired in the absence of $G_{q}$ (Damian et al. 2018). Further investigation using intramolecular time-resolved luminescence resonance energy transfer in HEK293 cells showed that GHSR1a-DRD2 association may affect the active conformation of $\mathrm{G} \alpha_{\mathrm{i}}$. The authors propose a model in which GHSR1a exerts an allosteric effect on the adjacent receptors that modifies DRD2 conformation and its ability to trigger $\mathrm{G}$ protein activation (Damian et al. 2018).

Recently, a role for GHSR1a-DRD2 heteromers has been shown in the regulation of voltage-gated calcium channel currents in pre-synaptic terminals (Cordisco Gonzalez et al. 2020). Activation of $\mathrm{Ca}_{\mathrm{V}} 2.2$ channels in pre-synaptic terminals contributes to neurotransmitter release, and both ghrelin-mediated activation of GHSR1a and quinpirole activation of DRD2 have been shown to reduce $\mathrm{Ca}_{\mathrm{V}} 2.2$ channel currents and impair neurotransmitter release (Cordisco Gonzalez et al. 2020). DRD2 reduces $\mathrm{Ca}_{\mathrm{v}} 2.2$ in part by direct inhibition by $\mathrm{G} \beta \gamma$ (Kisilevsky \& Zamponi 2008). Studies in cultured hypothalamic neurons showed that co-expression of GHSR1a and DRD2 reduced the quinpirole-induced DRD2-mediated inhibition of $\mathrm{Ca}_{\mathrm{v}} 2.2$ currents (Cordisco Gonzalez et al. 2020). Further studies in transfected HEK293T cells confirmed that GHSR1a co-expression with DRD2 reduced the dopamine-induced inhibition of $\mathrm{Ca}_{\mathrm{v}} 2.2$ currents, which was blocked when cells were pre-incubated with the GHSR1a inverse agonist substance $P$ or with dominant-negative $G_{q}$. However, co-expression with MAS-GRK2-ct, a peptide that sequesters $\mathrm{G} \beta \gamma$ from the $G$ protein complex, had no effect on GHSR1amediated reductions in DRD2-mediated $\mathrm{Ca}_{\mathrm{V}} 2.2$ inhibition (Cordisco Gonzalez et al. 2020). The authors concluded that the $\mathrm{G} \beta \gamma$ role in dopamine-mediated inhibition of $\mathrm{Ca}_{\mathrm{V}} 2.2$ is lost when GHSR is co-expressed, likely due to preferential coupling of $G \beta \gamma$ to $G_{q}$ rather than $G_{i}$, and reduces the ability of $\mathrm{G} \beta \gamma$ to bind to $\mathrm{Ca}_{\mathrm{v}} 2.2$ (Cordisco Gonzalez et al. 2020). A subsequent study showed that LEAP2 blocks the GHSR1a-D2R co-expression effects on $\mathrm{Ca}_{\mathrm{V}} 2.2$ in transfected HEK293T cells (Mustafa et al. 2021). 
Using FRET, the authors showed that LEAP2 does not disrupt the formation of the GHSR-D2R heteromer, but stabilises GHSR1a in an inactive conformation (Mustafa et al. 2021). These studies provide evidence that targeting GHSR1a and DRD2 heteromers could allow selective fine-tuning of DRD2 signalling as neurons expressing DRD2 alone will be unaffected, which could improve selectivity of drug treatments and reduce their side effects (Kern et al. 2012).

\section{GHSR1a interaction with GHS-R1b}

GHSR1b is a naturally occurring, highly expressed, but inactive truncated splice variant of GHSR1a (Gnanapavan et al. 2002, Navarro et al. 2016). However, GHSR1b can interact with GHSR1a to exert a dominant-negative effect on its signalling (Leung et al. 2007). In 2007, GHSR1a was reported to form homodimers and heterodimers with GHSR1b using saturation BRET and immunoprecipitation in HEK293 cells overexpressing the two proteins (Leung et al. 2007). GHSR1b had low, or absent, affinity for ghrelin; while constitutive activity, measured by radioactive IP production, was reduced in GHSR1a-GHSR1b complexes, although ghrelin-induced IP production was still present (Leung etal. 2007). The ability to phosphorylate extracellular signal-regulated kinase (ERK1/2) was unaffected by GHSR1b. Using ELISA, the authors showed a reduction in total GHSR1a and cell surface expression, indicating that GHSR1b may retain GHSR1a intracellularly, with confocal microscopy showing that this may be in nuclear or perinuclear locations (Leung et al. 2007). A subsequent study by the same group using sucrose-density gradients and saturation BRET showed GHSR1a-GHSR1b complexes form in the endoplasmic reticulum (ER) rather than the nucleus, and ERK1/2 signalling from these fractions declined when GHSR1b was co-transfected (Chow et al. 2012). These studies suggest the possibility that GHSR1a can signal from other locations than the plasma membrane, although this latter observation requires confirmation in further studies. The authors conclude that GHSR1a homodimerisation is a prerequisite for receptor trafficking to the cell surface, and that in the presence of GHSR1b, GHSR1a must compete to form functional dimers. The binding of GHSR1a and GHSR1b leads to a reduction in the activation of PLC, yet upon maximal stimulation by its ligand, GHSR1a can express sufficiently at cell surfaces to mediate signalling (Chow et al. 2012).

Another research group also examined GHSR1aGHSR1b heterodimerisation by reconstitution in lipid nanodiscs (Mary et al. 2013). These studies confirmed that ligand-binding to GHSR1b is absent, indicating the importance of the TM6 and TM7 domains for ligand recognition, which was subsequently confirmed by receptor structural analyses (Shiimura et al. 2020); while GHSR1aGHSR1b heterodimers can bind to a ligand (Mary et al. 2013). In contrast to similar signalling properties between GHSR1a monomers and homodimers, dimerisation with GHSR1b in lipid discs: abolished $\beta$-arrestin recruitment; prevented basal Gq activation; and was unable to mediate ghrelin-induced signalling (Mary et al. 2013). Finally, the impact of dimerisation on the receptor structure was explored using bimane labelling of TM7 as a fluorescent reporter to explore changes in GHSR1a conformation. In the absence of ligand, bimane emission properties were similar whether GHSR1a was monomeric, homodimeric, or heterodimeric, implying that dimerisation may not primarily affect the basal conformational state of the ghrelin receptor (Mary et al. 2013). In addition to the $G$ protein heterotrimer, the ligand-free GHSR1a monomer was associated with a significant change in bimane emission intensity consistent with stabilisation of the active conformation of the receptor that is responsible for GHSR1a's high constitutive activity (Mary et al. 2013). The GHSR1a homodimer had intermediate emission spectra compared to the monomer, which has previously been shown for leukotriene-B4 receptors and was attributed to asymmetry in the dimer, with only one of the two protomers in the fully active state (Damian et al. 2006). The GHSR1aGHSR1b heterodimer, in contrast, showed no change in emission, indicating that the truncated receptor prevents GHSR1a from undergoing Gq-induced conformational changes, and explains the loss of constitutive and agonistinduced activity observed for these heterodimers (Mary et al. 2013).

These studies identified two mechanisms by which GHSR1b may have a dominant-negative effect on GHSR1a: (i) intracellular retention and loss of plasma membrane expression and (ii) an allosteric mechanism that prevents conformational changes required for GHSR1a signalling. A subsequent study by a third research group examined the GHSR1a-GHSR1b heterodimer in further detail, this time also addressing the physiological effect of such heterodimerisation (Navarro et al. 2016). Using overexpressed receptors in HEK293T cells, co-localisation of GHSR1a and GHSR1b in intracellular structures was confirmed and GHSR1b expression reduced the amount of GHSR1a in the plasma membrane. However, GHSR1b did not reduce total GHSR1a expression, nor did it prevent GHSR1a-GHSR1b heterodimer expression in the plasma

This work is licensed under a Creative Commons Attribution 4.0 International License. ed from Bioscientifica.com at 04/26/2023 09:31:29AM 
membrane (Navarro et al. 2016). Label-free dynamic mass redistribution assays were used to examine GHSR1aGHSR1b signalling and showed ghrelin-induced cAMP signalling was reduced by inhibition of $\mathrm{G}_{\mathrm{i} / \mathrm{o}}$. Moreover, these assays showed that low expression of GHSR1b can potentiate GHSR1a-mediated $G_{i / o}$ signalling. A similar phenomenon was seen for ghrelin-induced increases in cytosolic calcium, phosphorylation of ERK1/2, and recruitment of $\beta$-arrestin, which were mediated by $G_{q}$ when GHSR1a was expressed alone and absent from GHSR1b-only cells, but low expression of GHSR1b with GHSR1a resulted in potentiation of $\mathrm{G}_{\mathrm{i}}$ signalling (Navarro et al. 2016).

In contrast to findings in HEK293T cells, in striatal and hippocampal neurons, there was an increase in $\mathrm{G}_{\mathrm{s}}$ mediated elevations in cAMP. A DRD1 antagonist blocked this ghrelin-induced cAMP accumulation in striatal but not hippocampal neurons, indicating the involvement of DRD1 in the striatal GHSR1a-G coupling (Navarro et al. 2016). Studies in HEK293T cells demonstrated that DRD1 co-expression promoted a switch in GHSR1a-G protein coupling to $\mathrm{G}_{\mathrm{s}}$, but only upon co-expression of GHSR1b. BRET assays confirmed complexes can form between GHSR1a and DRD1, but only in the presence of GHSR1b (Navarro et al. 2016) (Fig. 1). Thus, these studies imply that signalling by ghrelin is determined by the stoichiometry of GHSR1a to GHSR1b in the plasma membrane, and that findings of intracellular retention are due to artificially high expression of GHSR1b in some studies. This mechanism of G protein switching by GHSR1a, when co-expressed with GHSR1b, will need to be considered when designing compounds targeting heterodimers. Moreover, these studies demonstrate the importance of replicating studies in physiologically relevant cells in which receptor stoichiometries are accurate and tissue-specific effects can be observed.

\section{GHSR1a interaction with neuronal sigma-1 receptor $(\sigma 1 \mathrm{R})$}

The $\sigma 1 \mathrm{R}$ is a two transmembrane pass protein that is preferentially expressed at the ER and acts as a molecular chaperone. The native ligand for the receptor is unknown; however, cocaine can bind to the receptor (Lever et al. 2016). As cocaine suppresses appetite, and GPCRs including DRD1 and DRD2 have been shown to interact with $\sigma 1 \mathrm{R}$, heteromerisation between GHSR1a and $\sigma 1 \mathrm{R}$ was investigated. Using HEK293T cells, GHSR1a and $\sigma 1 \mathrm{R}$ were shown to colocalise using immunocytochemistry and BRET assays, with GHSR1a TM1 and TM2 most likely to interact with $\sigma 1 \mathrm{R}$, identified using BiFC and cell-penetrating peptides (Aguinaga et al. 2019). Computational modelling using molecular dynamics simulations indicated that a single GHSR1a protomer would be unable to interact with both $\sigma 1 \mathrm{R}$ at $\mathrm{TM} 1 / 2$ and the G protein at the intracellular receptor face, and therefore it is likely that dimers of GHSR1a (or GHSR1a-GHSR1b) are required (Aguinaga et al. 2019). Cell treatment with cocaine, or the $\sigma 1 \mathrm{R}$ agonist PRE084, increased $\sigma 1 \mathrm{R}-\mathrm{GHSR} 1$ a co-localisation and suppressed GHSR1a-mediated cAMP reductions and phosphorylation of ERK1/2. Disruption of interactions between $\sigma 1$-receptor and GHSR1a by TM1 interference peptide blocked the effect of cocaine on GHSR1a function. As cocaine's main effects on the CNS are exerted in the striatum, studies were repeated in primary striatal neurons, which showed enhanced $\sigma 1 \mathrm{R}$-GHSR1a interactions by PLA and impaired GHSR1a-mediated signalling on pre-treatment with cocaine or PRE-084 (Aguinaga et al. 2019).

While these studies indicate that $\sigma 1 \mathrm{R}$-GHSR1a interactions may occur in the striatum and could contribute to the mechanism by which cocaine suppresses appetite, further investigations are required to establish whether cocaine affects ghrelin-mediated physiological functions in vivo. As $\sigma 1 \mathrm{R}$ and GHSR1a form interactions with both DRD1 and DRD2, it is possible that complex heteromers could form between different combinations of these proteins, and the concentration of ligand that relevant tissues are exposed to could determine the formation of these heteromers and their effects on appetite and reward pathways.

\section{GHSR1a interaction with oxytocin receptor}

The oxytocin receptor (OTR) is a $\mathrm{G}_{\mathrm{q}}$-coupled receptor that is expressed on reproductive tissues and brain regions including the hypothalamus, hippocampus, and amygdala (Gimpl \& Fahrenholz 2001). The oxytocin neuropeptide acts as the primary ligand for the receptor and has welldescribed functions in bonding, reproduction, and stress responses (Gimpl \& Fahrenholz 2001). Oxytocin has also been shown to regulate other hormones including ghrelin, although these studies disagree on whether oxytocin enhances or inhibits ghrelin secretion (Vila et al. 2009, Iwakura et al. 2011).

A single study has investigated interactions between GHSR1a and OTR (Wallace Fitzsimons et al. 2019). Co-localisation between OTR and GHSR1a was shown by confocal microscopy, and close proximity of the receptors

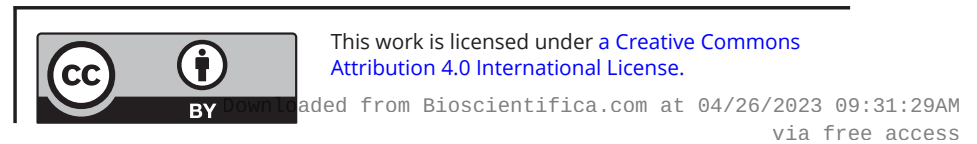


was confirmed by FRET in HEK293 cells. Additionally, the receptors are expressed in the same structures in hypothalamic and hippocampal postnatal rat neuronal cultures, indicating that the receptors could theoretically interact in physiological systems (Wallace Fitzsimons et al. 2019). Oxytocin-induced $\mathrm{Ca}^{2+}{ }_{i}$ signalling was reduced in cells co-expressing both OTR and GHSR1a, while GHSR1a responses remained normal (Wallace Fitzsimons et al. 2019). This was prevented by pre-treatment of cells with the GHSR1a antagonist JMV2959. Confocal imaging showed that stimulation with ligands for either receptor-induced increased internalisation of OTR and GHSR1a, indicating that the receptors may co-internalise (Wallace Fitzsimons et al. 2019).

While this study provides some evidence that OTR and GHSR1a receptors may interact, a number of questions remain, which require further study to address. This includes determining how increased co-internalisation of both OTR and GHSR1a results in impaired signalling of only the OTR, as well as investigating the physiological relevance of such an interaction.

\section{GHSR1a interaction with prostanoid receptors}

Prostanoid receptors are GPCRs that bind the arachidonic acid metabolites prostaglandins and thromboxane $\mathrm{A}_{2}$. Their functions include relaxation and contraction of smooth muscle, particularly during the inflammatory process and in platelet activation (Narumiya et al. 1999). Ghrelin and GHSR1a have also been described to regulate inflammatory responses and vasodilation. GHSR1 mRNA is present in vascular smooth muscle cells, cardiomyocytes, monocytes, T-lymphocytes, neutrophils, and macrophages; ghrelin increases blood flow and decreases arterial pressure in humans; and ghrelin inhibits the production of leptininduced proinflammatory cytokines, while leptin upregulates GHSR1a expression on human T-lymphocytes (Dixit et al. 2004, Waseem et al. 2008). This suggests the existence of a reciprocal regulatory network by which ghrelin and leptin control immune cell activation and inflammation, coupling the metabolic axis to the immune system (Dixit et al. 2004).

These findings led to the hypothesis that GHSR1a and prostanoid receptors may cross-talk or interact to regulate each other's activity. One study investigated the interaction between transiently transfected GHSR1a and the prostaglandin $\mathrm{E}_{2}$ receptor subtype $\mathrm{EP}_{3-\mathrm{I}}$ and thromboxane prostanoid A2 receptor, TP $\alpha$, in HEK293 cells (Chow et al. 2008). GHS-R1a/EP ${ }_{3-\mathrm{I}}$ and GHS-R1a/TP $\alpha$ heteromers were demonstrated by saturation BRET, and evidence of co-immunoprecipitation between the receptors led the authors to state complexes are stable (Chow et al. 2008). Co-transfection of GHSR1a and prostanoid receptors reduced GHSR1a signalling via three mechanisms: decreased total GHSR1a expression, increased intracellular localisation of GHSR1a, and reduced GHSR1a constitutive activity. These findings require replication in more physiologically relevant cell lines or whole animal models; however, this mechanism could explain findings that ghrelin and prostacyclins have opposite actions in smooth muscle in the regulation of inflammation.

\section{Conclusions}

GHSR1a has been shown to interact with proteins with diverse functions in multiple tissues, and understanding how this modifies signalling could provide novel strategies to target receptors in specific locations. However, many of these studies rely on overexpression of proteins in cell lines and reported heterodimers could be artefacts of receptor crowding and random collisions. Investigations in physiologically relevant tissues, assessment of endogenous proteins, and replication in independent laboratories are required for many of these reported interactions before advancement to drug discovery. GHSR1a interacting proteins do, however, represent a potentially exciting new target for appetite regulation, Alzheimer's disease, insulin secretion, and inflammation.

\section{Declaration of interest}

The authors declare that there is no conflict of interest that could be perceived as prejudicing the impartiality of this review.

\section{Funding}

C M G is in receipt of research funding in the form of an Academy of Medical Sciences Springboard Award (Ref: SBF004|1034), which is supported by the British Heart Foundation, Diabetes UK, the Global Challenges Research Fund, the Government Department of Business, Energy and Industrial Strategy and the Wellcome Trust.

\section{References}

Adriaenssens AE, Svendsen B, Lam BY, Yeo GS, Holst JJ, Reimann F \& Gribble FM 2016 Transcriptomic profiling of pancreatic alpha, beta and delta cell populations identifies delta cells as a principal target for ghrelin in mouse islets. Diabetologia 59 2156-2165. (https://doi. org/10.1007/s00125-016-4033-1)

Aguinaga D, Medrano M, Cordomí A, Jiménez-Rosés M, Angelats E, Casanovas M, Vega-Quiroga I, Canela EI, Petrovic M, Gysling K,

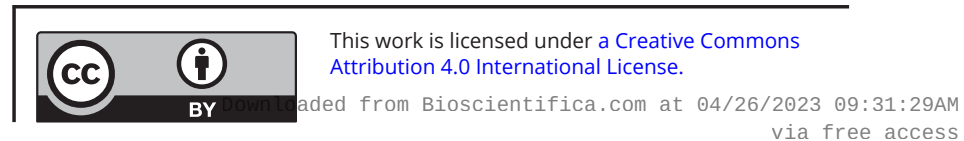


et al. 2019 Cocaine blocks effects of hunger hormone, ghrelin, via interaction with neuronal Sigma-1 receptors. Molecular Neurobiology 56 1196-1210. (https://doi.org/10.1007/s12035-018-1140-7)

Asai M, Ramachandrappa S, Joachim M, Shen Y, Zhang R, Nuthalapati N, Ramanathan V, Strochlic DE, Ferket P, Linhart K, et al. 2013 Loss of function of the melanocortin 2 receptor accessory protein 2 is associated with mammalian obesity. Science 341 275-278. (https://doi. org/10.1126/science.1233000)

Brunetti L, Recinella L, Orlando G, Michelotto B, Di Nisio C \& Vacca M 2002 Effects of ghrelin and amylin on dopamine, norepinephrine and serotonin release in the hypothalamus. European Journal of Pharmacology 454 189-192. (https://doi.org/10.1016/s00142999(02)02552-9)

Chan LF, Webb TR, Chung TT, Meimaridou E, Cooray SN, Guasti L, Chapple JP, Egertova M, Elphick MR, Cheetham ME, et al. 2009 MRAP and MRAP2 are bidirectional regulators of the melanocortin receptor family. PNAS 106 6146-6151. (https://doi.org/10.1073/ pnas.0809918106)

Chow KB, Leung PK, Cheng CH, Cheung WT \& Wise H 2008 The constitutive activity of ghrelin receptors is decreased by co-expression with vasoactive prostanoid receptors when over-expressed in human embryonic kidney 293 cells. International Journal of Biochemistry and Cell Biology 40 2627-2637. (https://doi.org/10.1016/j.biocel.2008.05.008)

Chow KB, Sun J, Chu KM, Tai Cheung W, Cheng CH \& Wise H 2012 The truncated ghrelin receptor polypeptide (GHS-R1b) is localized in the endoplasmic reticulum where it forms heterodimers with ghrelin receptors (GHS-R1a) to attenuate their cell surface expression. Molecular and Cellular Endocrinology 348 247-254. (https://doi.org/10.1016/j. mce.2011.08.034)

Cordisco Gonzalez S, Mustafa ER, Rodriguez SS, Perello M \& Raingo J 2020 Dopamine receptor Type 2 and ghrelin receptor coexpression alters CaV2.2 modulation by G protein signaling cascades. ACS Chemical Neuroscience 11 3-13. (https://doi.org/10.1021/acschemneuro.9b00426)

Costantini VJA, Vicentini E, Sabbatini FM, Valerio E, Lepore S, Tessari M, Sartori M, Michielin F, Melotto S, Bifone A, et al. 2011 GSK1614343, a novel ghrelin receptor antagonist, produces an unexpected increase of food intake and body weight in rodents and dogs. Neuroendocrinology 94 158-168. (https://doi.org/10.1159/000328968)

Currie PJ, John CS, Nicholson ML, Chapman CD \& Loera KE 2010 Hypothalamic paraventricular 5-hydroxytryptamine inhibits the effects of ghrelin on eating and energy substrate utilization. Pharmacology, Biochemistry, and Behavior 97 152-155. (https://doi. org/10.1016/j.pbb.2010.05.027)

Damian M, Martin A, Mesnier D, Pin JP \& Baneres JL 2006 Asymmetric conformational changes in a GPCR dimer controlled by G-proteins. EMBO Journal 25 5693-5702. (https://doi.org/10.1038/ sj.emboj.7601449)

Damian M, Pons V, Renault P, M'Kadmi C, Delort B, Hartmann L, Kaya AI, Louet M, Gagne D, Ben Haj Salah K, et al. 2018 GHSR-D2R heteromerization modulates dopamine signaling through an effect on G protein conformation. PNAS 115 4501-4506. (https://doi. org/10.1073/pnas.1712725115)

Dezaki K, Kakei M \& Yada T 2007 Ghrelin uses Galphai2 and activates voltage-dependent $\mathrm{K}+$ channels to attenuate glucose-induced $\mathrm{Ca} 2+$ signaling and insulin release in islet beta-cells: novel signal transduction of ghrelin. Diabetes 56 2319-2327. (https://doi. org/10.2337/db07-0345)

DiGruccio MR, Mawla AM, Donaldson CJ, Noguchi GM, Vaughan J, Cowing-Zitron C, van der Meulen T \& Huising MO 2016 Comprehensive alpha, beta and delta cell transcriptomes reveal that ghrelin selectively activates delta cells and promotes somatostatin release from pancreatic islets. Molecular Metabolism 5 449-458. (https:// doi.org/10.1016/j.molmet.2016.04.007)

Dixit VD, Schaffer EM, Pyle RS, Collins GD, Sakthivel SK, Palaniappan R, Lillard Jr JW \& Taub DD 2004 Ghrelin inhibits leptin- and activationinduced proinflammatory cytokine expression by human monocytes and T cells. Journal of Clinical Investigation 114 57-66. (https://doi. org/10.1172/JCI21134)

Dorr JM, Scheidelaar S, Koorengevel MC, Dominguez JJ, Schafer M, van Walree CA \& Killian JA 2016 The styrene-maleic acid copolymer: a versatile tool in membrane research. European Biophysics Journal 45 3-21. (https://doi.org/10.1007/s00249-015-1093-y)

Fernandez G, Cabral A, Andreoli MF, Labarthe A, M'Kadmi C, Ramos JG, Marie J, Fehrentz JA, Epelbaum J, Tolle V, et al. 2018 Evidence supporting a role for constitutive ghrelin receptor signaling in fastinginduced hyperphagia in male mice. Endocrinology 159 1021-1034. (https://doi.org/10.1210/en.2017-03101)

Ge X, Yang H, Bednarek MA, Galon-Tilleman H, Chen P, Chen M, Lichtman JS, Wang Y, Dalmas O, Yin Y, et al. 2018 LEAP2 is an endogenous antagonist of the ghrelin receptor. Cell Metabolism 27461. e6-469.e6. (https://doi.org/10.1016/j.cmet.2017.10.016)

Ghamari-Langroudi M, Cakir I, Lippert RN, Sweeney P, Litt MJ, Ellacott KLJ \& Cone RD 2018 Regulation of energy rheostasis by the melanocortin-3 receptor. Science Advances 4 eaat0866. (https://doi.org/10.1126/sciadv. aat0866)

Gimpl G \& Fahrenholz F 2001 The oxytocin receptor system: structure, function, and regulation. Physiological Reviews 81 629-683. (https:// doi.org/10.1152/physrev.2001.81.2.629)

Gnanapavan S, Kola B, Bustin SA, Morris DG, McGee P, Fairclough P, Bhattacharya S, Carpenter R, Grossman AB \& Korbonits M 2002 The tissue distribution of the mRNA of ghrelin and subtypes of its receptor, GHS-R, in humans. Journal of Clinical Endocrinology and Metabolism $\mathbf{8 7}$ 2988. (https://doi.org/10.1210/jcem.87.6.8739)

Gomes I, Bobeck EN, Margolis EB, Gupta A, Sierra S, Fakira AK, Fujita W, Muller TD, Muller A, Tschop MH, et al. 2016 Identification of GPR83 as the receptor for the neuroendocrine peptide PEN. Science Signaling 9 ra43. (https://doi.org/10.1126/scisignal.aad0694)

Gutierrez JA, Solenberg PJ, Perkins DR, Willency JA, Knierman MD, Jin Z, Witcher DR, Luo S, Onyia JE \& Hale JE 2008 Ghrelin octanoylation mediated by an orphan lipid transferase. PNAS 105 6320-6325. (https://doi.org/10.1073/pnas.0800708105)

Hassouna R, Labarthe A, Zizzari P, Videau C, Culler M, Epelbaum J \& Tolle V 2013 Actions of agonists and antagonists of the ghrelin/GHS-R pathway on GH secretion, appetite, and cFos activity. Frontiers in Endocrinology 4 25. (https://doi.org/10.3389/fendo.2013.00025)

Howard AD, Feighner SD, Cully DF, Arena JP, Liberator PA, Rosenblum CI, Hamelin M, Hreniuk DL, Palyha OC, Anderson J, et al. 1996 A receptor in pituitary and hypothalamus that functions in growth hormone release. Science 273 974-977. (https://doi.org/10.1126/ science.273.5277.974)

Inutsuka A, Inui A, Tabuchi S, Tsunematsu T, Lazarus M \& Yamanaka A 2014 Concurrent and robust regulation of feeding behaviors and metabolism by orexin neurons. Neuropharmacology 85 451-460. (https://doi.org/10.1016/j.neuropharm.2014.06.015)

Iwakura H, Ariyasu H, Hosoda H, Yamada G, Hosoda K, Nakao K, Kangawa K \& Akamizu T 2011 Oxytocin and dopamine stimulate ghrelin secretion by the ghrelin-producing cell line, MGN3-1 in vitro. Endocrinology 152 2619-2625. (https://doi.org/10.1210/en.2010-1455)

Jiang H, Betancourt L \& Smith RG 2006 Ghrelin amplifies dopamine signaling by cross talk involving formation of growth hormone secretagogue receptor/dopamine receptor subtype 1 heterodimers. Molecular Endocrinology 20 1772-1785. (https://doi.org/10.1210/ me.2005-0084)

Johnson PM \& Kenny PJ 2010 Dopamine D2 receptors in addiction-like reward dysfunction and compulsive eating in obese rats. Nature Neuroscience 13 635-641. (https://doi.org/10.1038/nn.2519)

Kern A, Albarran-Zeckler R, Walsh HE \& Smith RG 2012 Apo-ghrelin receptor forms heteromers with DRD2 in hypothalamic neurons and is essential for anorexigenic effects of DRD2 agonism. Neuron 73 317-332. (https://doi.org/10.1016/j.neuron.2011.10.038)

Kern A, Mavrikaki M, Ullrich C, Albarran-Zeckler R, Brantley AF \& Smith RG 2015 Hippocampal dopamine/DRD1 signaling dependent 
on the ghrelin receptor. Cell 163 1176-1190. (https://doi.org/10.1016/j. cell.2015.10.062)

Kisilevsky AE \& Zamponi GW 2008 D2 dopamine receptors interact directly with N-type calcium channels and regulate channel surface expression levels. Channels 2 269-277. (https://doi.org/10.4161/ chan.2.4.6402)

Kojima M, Hosoda H, Date Y, Nakazato M, Matsuo H \& Kangawa K 1999 Ghrelin is a growth-hormone-releasing acylated peptide from stomach. Nature 402 656-660. (https://doi.org/10.1038/45230)

Leung PK, Chow KB, Lau PN, Chu KM, Chan CB, Cheng CH \& Wise H 2007 The truncated ghrelin receptor polypeptide (GHS-R1b) acts as a dominant-negative mutant of the ghrelin receptor. Cellular Signalling 19 1011-1022. (https://doi.org/10.1016/j.cellsig.2006.11.011)

Lever JR, Fergason-Cantrell EA, Watkinson LD, Carmack TL, Lord SA, Xu R, Miller DK \& Lever SZ 2016 Cocaine occupancy of sigma1 receptors and dopamine transporters in mice. Synapse 70 98-111. (https://doi. org/10.1002/syn.21877)

Mary S, Fehrentz JA, Damian M, Gaibelet G, Orcel H, Verdié P, Mouillac B, Martinez J, Marie J \& Banères JL 2013 Heterodimerization with its splice variant blocks the ghrelin receptor $1 \mathrm{a}$ in a non-signaling conformation: a study with a purified heterodimer assembled into lipid discs. Journal of Biological Chemistry 288 24656-24665. (https://doi.org/10.1074/jbc. M113.453423)

Meguid MM, Fetissov SO, Varma M, Sato T, Zhang L, Laviano A \& Rossi-Fanelli F 2000 Hypothalamic dopamine and serotonin in the regulation of food intake. Nutrition 16 843-857. (https://doi. org/10.1016/s0899-9007(00)00449-4)

Morgan DJ, Wei S, Gomes I, Czyzyk T, Mzhavia N, Pan H, Devi LA, Fricker LD \& Pintar JE 2010 The propeptide precursor proSAAS is involved in fetal neuropeptide processing and body weight regulation. Journal of Neurochemistry 113 1275-1284. (https://doi.org/10.1111/ j.1471-4159.2010.06706.x)

Muller TD, Muller A, Yi CX, Habegger KM, Meyer CW, Gaylinn BD, Finan B, Heppner K, Trivedi C, Bielohuby M, et al. 2013 The orphan receptor Gpr83 regulates systemic energy metabolism via ghrelin-dependent and ghrelin-independent mechanisms. Nature Communications 41968. (https://doi.org/10.1038/ncomms2968)

Muller TD, Nogueiras R, Andermann ML, Andrews ZB, Anker SD, Argente J, Batterham RL, Benoit SC, Bowers CY, Broglio F, et al. 2015 Ghrelin. Molecular Metabolism 4 437-460. (https://doi.org/10.1016/j. molmet.2015.03.005)

Muschamp JW, Hollander JA, Thompson JL, Voren G, Hassinger LC, Onvani S, Kamenecka TM, Borgland SL, Kenny PJ \& Carlezon Jr WA 2014 Hypocretin (orexin) facilitates reward by attenuating the antireward effects of its cotransmitter dynorphin in ventral tegmental area. PNAS 111 E1648-E1655. (https://doi.org/10.1073/ pnas.1315542111)

Mustafa ER, Cordisco Gonzalez S, Damian M, Cantel S, Denoyelle S, Wagner R, Schioth HB, Fehrentz JA, Baneres JL, Perello M, et al. 2021 LEAP2 impairs the capability of the growth hormone secretagogue receptor to regulate the dopamine 2 receptor signaling. Frontiers in Pharmacology 12 712437. (https://doi.org/10.3389/fphar.2021.712437)

Narumiya S, Sugimoto Y \& Ushikubi F 1999 Prostanoid receptors: structures, properties, and functions. Physiological Reviews 79 1193-1226. (https://doi.org/10.1152/physrev.1999.79.4.1193)

Navarro G, Aguinaga D, Angelats E, Medrano M, Moreno E, Mallol J, Cortés A, Canela EI, Casadó V, McCormick PJ, et al. 2016 A significant role of the truncated ghrelin receptor GHS-R1b in ghrelin-induced signaling in neurons. Journal of Biological Chemistry 291 13048-13062. (https://doi.org/10.1074/jbc.M116.715144)

Nonogaki K, Ohashi-Nozue K \& Oka Y 2006 A negative feedback system between brain serotonin systems and plasma active ghrelin levels in mice. Biochemical and Biophysical Research Communications 341 703-707. (https://doi.org/10.1016/j.bbrc.2006.01.021)

Pantel J, Legendre M, Cabrol S, Hilal L, Hajaji Y, Morisset S, Nivot S, VieLuton MP, Grouselle D, de Kerdanet M, et al. 2006 Loss of constitutive activity of the growth hormone secretagogue receptor in familial short stature. Journal of Clinical Investigation 116 760-768. (https://doi. org/10.1172/JCI25303)

Park S, Jiang H, Zhang H \& Smith RG 2012 Modification of ghrelin receptor signaling by somatostatin receptor-5 regulates insulin release. PNAS 109 19003- 19008 .(https://doi.org/10.1073/ pnas.1209590109)

Perello M, Cabral A, Cornejo MP, De Francesco PN, Fernandez G \& Uriarte M 2019 Brain accessibility delineates the central effects of circulating ghrelin. Journal of Neuroendocrinology 31 e12677. (https:// doi.org/10.1111/jne.12677)

Petersen PS, Woldbye DP, Madsen AN, Egerod KL, Jin C, Lang M, Rasmussen M, Beck-Sickinger AG \& Holst B 2009 In vivo characterization of high Basal signaling from the ghrelin receptor. Endocrinology 150 4920-4930. (https://doi.org/10.1210/en.2008-1638)

Rediger A, Tarnow P, Bickenbach A, Schaefer M, Krude H, Gruters A \& Biebermann H 2009 Heterodimerization of hypothalamic G-proteincoupled receptors involved in weight regulation. Obesity Facts 2 80-86. (https://doi.org/10.1159/000209862)

Rediger A, Piechowski CL, Yi CX, Tarnow P, Strotmann R, Grüters A, Krude H, Schöneberg T, Tschöp MH, Kleinau G, et al. 2011 Mutually opposite signal modulation by hypothalamic heterodimerization of ghrelin and melanocortin-3 receptors. Journal of Biological Chemistry 286 39623-39631. (https://doi.org/10.1074/jbc.M111.287607)

Rouault AAJ, Lee AA \& Sebag JA 2017 Regions of MRAP2 required for the inhibition of orexin and prokineticin receptor signaling. Biochimica et Biophysica Acta: Molecular Cell Research 1864 2322-2329. (https://doi. org/10.1016/j.bbamcr.2017.09.008)

Rouault AAJ, Rosselli-Murai LK, Hernandez CC, Gimenez LE, Tall GG \& Sebag JA 2020 The GPCR accessory protein MRAP2 regulates both biased signaling and constitutive activity of the ghrelin receptor GHSR1a. Science Signaling 13. (https://doi.org/10.1126/scisignal. aax4569)

Schellekens H, van Oeffelen WE, Dinan TG \& Cryan JF 2013 Promiscuous dimerization of the growth hormone secretagogue receptor (GHS-R1a) attenuates ghrelin-mediated signaling. Journal of Biological Chemistry 288 181-191. (https://doi.org/10.1074/jbc.M112.382473)

Schellekens H, De Francesco PN, Kandil D, Theeuwes WF, McCarthy T, van Oeffelen WE, Perello M, Giblin L, Dinan TG \& Cryan JF 2015 Ghrelin's orexigenic effect is modulated via a serotonin $2 \mathrm{C}$ receptor interaction. ACS Chemical Neuroscience 6 1186-1197. (https://doi.org/10.1021/ cn500318q)

Sebag JA, Zhang C, Hinkle PM, Bradshaw AM \& Cone RD 2013 Developmental control of the melanocortin-4 receptor by MRAP2 proteins in zebrafish. Science 341 278-281. (https://doi.org/10.1126/ science.1232995)

Shiimura Y, Horita S, Hamamoto A, Asada H, Hirata K, Tanaka M, Mori K, Uemura T, Kobayashi T, Iwata S, et al. 2020 Structure of an antagonistbound ghrelin receptor reveals possible ghrelin recognition mode. Nature Communications 11 4160. (https://doi.org/10.1038/s41467-02017554-1)

Srisai D, Yin TC, Lee AA, Rouault AAJ, Pearson NA, Grobe JL \& Sebag JA 2017 MRAP2 regulates ghrelin receptor signaling and hunger sensing. Nature Communications 8 713. (https://doi.org/10.1038/s41467-01700747-6)

Tian J, Guo L, Sui S, Driskill C, Phensy A, Wang Q, Gauba E, Zigman JM, Swerdlow RH, Kroener S, et al. 2019 Disrupted hippocampal growth hormone secretagogue receptor $1 \alpha$ interaction with dopamine receptor D1 plays a role in Alzheimer's disease. Science Translational Medicine 11 eaav6278. (https://doi.org/10.1126/scitranslmed.aav6278)

Tong J, Prigeon RL, Davis HW, Bidlingmaier M, Kahn SE, Cummings DE, Tschop MH \& D'Alessio D 2010 Ghrelin suppresses glucose-stimulated insulin secretion and deteriorates glucose tolerance in healthy humans. Diabetes 59 2145-2151. (https://doi.org/10.2337/db10-0504)

Torz LJ, Osborne-Lawrence S, Rodriguez J, He Z, Cornejo MP, Mustafa ER, Jin C, Petersen N, Hedegaard MA, Nybo M, et al. 2020

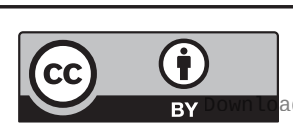

This work is licensed under a Creative Commons Attribution 4.0 International License. Aed from Bioscientifica com at $04 / 26 / 2023$ 09:31:29AM 
Metabolic insights from a GHSR-A203E mutant mouse model. Molecular Metabolism 39 101004. (https://doi.org/10.1016/j. molmet.2020.101004)

Vila G, Riedl M, Resl M, van der Lely AJ, Hofland LJ, Clodi M \& Luger A 2009 Systemic administration of oxytocin reduces basal and lipopolysaccharide-induced ghrelin levels in healthy men. Journal of Endocrinology 203 175-179. (https://doi.org/10.1677/JOE-09-0227)

Wallace Fitzsimons SE, Chruscicka B, Druelle C, Stamou P, Nally K, Dinan TG, Cryan JF \& Schellekens H 2019 A ghrelin receptor and oxytocin receptor heterocomplex impairs oxytocin mediated signalling. Neuropharmacology 152 90-101. (https://doi.org/10.1016/j. neuropharm.2018.12.022)

Waseem T, Duxbury M, Ito H, Ashley SW \& Robinson MK 2008 Exogenous ghrelin modulates release of pro-inflammatory and anti-inflammatory cytokines in LPS-stimulated macrophages through distinct signaling pathways. Surgery 143 334-342. (https://doi.org/10.1016/j. surg.2007.09.039)

Wellman PJ, Davis KW \& Nation JR 2005 Augmentation of cocaine hyperactivity in rats by systemic ghrelin. Regulatory Peptides $\mathbf{1 2 5}$ 151-154. (https://doi.org/10.1016/j.regpep.2004.08.013)

Xue Q, Bai B, Ji B, Chen X, Wang C, Wang P, Yang C, Zhang R, Jiang Y, Pan Y, et al. 2018 Ghrelin through GHSR1a and OX1R heterodimers reveals a Gas-cAMP-cAMP response element binding protein signaling pathway in vitro. Frontiers in Molecular Neuroscience 11 245. (https://doi. org/10.3389/fnmol.2018.00245)

Yin TC, Bauchle CJ, Rouault AAJ, Stephens SB \& Sebag JA 2020 The insulinostatic effect of ghrelin requires MRAP2 expression in delta cells. iScience 23 101216. (https://doi.org/10.1016/j.isci.2020.101216)

Received in final form 5 September 2021

Accepted 18 October 2021

Accepted Manuscript published online 19 October 2021 https://joe.bioscientifica.com

https://doi.org/10.1530/JOE-21-0206 (c) 2021 The authors Published by Bioscientifica Ltd. Printed in Great Britain
This work is licensed under a Creative Commons Attribution 4.0 International License.

ded from Bioscientifica.com at 04/26/2023 09:31:29AM 